\title{
USING A BLOG TO ENGAGE STUDENTS IN LITERATURE SEARCH SKILLS SESSIONS
}

Dupuis, J.

Steacie Science \& Engineering Library, York University, Toronto, Ontario Canada

jdupuis@yorku.ca

\section{INTRODUCTION}

Social media is slowly working its way into higher education. According to a recent survey, 80 percent of all college and university professors use some sort of social media platform, such as Linkedin, Facebook, Twitter, Youtube, MySpace, Slideshare, blogs and others. Fifty-two percent of them use social media as a teaching tool. ${ }^{1}$ More and more, students will expect their higher education experience to be delivered on the platforms where they live their daily online lives.

Blogs in particular can play an important part in the classroom experience. Their interactivity can draw in students who might otherwise be too shy to participate in classroom discussions. They can also extend the discussion outside the time and place of the classroom itself. Instructors can also disseminate course-related information quickly and easily. Students can also really enjoy being part of a "cutting edge" educational experience. ${ }^{2}$

Andrew Eckford of York University finds blogs to be the best social media complement to the traditional classroom experience. ${ }^{3}$

\section{PROBLEM}

Librarians can play an important part in the educational process. They help faculty educate students in using the wealth of information resources available to them for their research and course work, both on the free Web and in journals, conferences, patent and standards collections, books and other databases that the library subscribes to. Librarians can also help faculty educate students about scholarly communications issues such as intellectual property, author rights and open access. The most common way that librarians help professors in the classroom is by helping students become aware of the universe of resources available via dedicated literature search skills sessions.

Librarians usually organize with the faculty either an in-class lecture and demonstration or, for smaller classes, a hands-on workshop in a library computer lab. In any of those sessions, the librarian faces a few challenges: 1) getting the students to remember what is talked about especially in terms of what resources are available to them, 2) that's these resources are easy to find and use, 3 ) that the librarian is available for further assistance and especially 4) getting the students' attention for a few minutes.

\section{SOLUTION}

If blogs are useful to professors in delivering their course content, they also have potential for librarians in delivering their content in literature search skills sessions. Some of the common ways to do this have included web pages, handouts or course management systems.

A blog, however, can be used to solve some of the librarian's challenges. The individual posts can hold the notes from the librarian's session; the post can be easily Googled by students or linked from a course web page; the blog itself and each individual post can have the librarian's contact information. As well, it can be linked to Instant Messaging systems such as Meebo. Not to mention the novelty value of the blog post and the ability to demonstrate tools such as Meebo can be genuine attention-grabbers.

In September, 2007 the Engineering Librarian at York University started the research skills sessions blog. It is located at http://www.yorku.ca/yul/cse/. Figure 1 shows what the page for Engineering 1000 looks like. Each post contains the notes for one particular course as well as contact information. The notes for each course contain the main resources that will be demonstrated in class as well as links and instructions to useful tools such as RefWorks. Figure 2 shows what some of the resources are further down in the page: ebook and journal articles databases that will be useful for first year engineering students. Examples of resources include Books 24x7, Google Patent Search and the IEEE Xplore journal, conference and standards database. The Meebo widget that can be used for the librarian to chat with students online is also visible in the upper left of Figure 1.

Some other features that can be used to engage students include links to the Steacie Library New Books Blog, recent Slashdot.org posts and the Steacie Library Twitter feed.

\section{ASSESSMENT}

The assessment of the blog's usefulness takes into account all the various courses and sessions it has been used for, not just Engineering. It has been used for Engineering, Natural Science, Science \& Technology Studies, Computer Science and others.

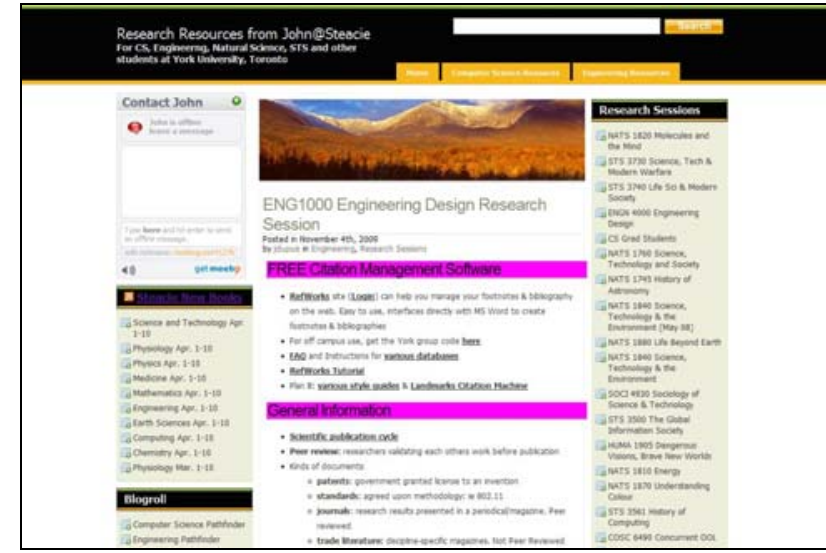

Figure 1: Engineering 1000 blog page.

In terms of the challenges outlined above, the blog has been quite successful. Google Analytics is used to track visits and pageviews for the blog since its inception. In that time, there have been nearly 50,000 pageviews; for the 2009-2010 academic year, over 12,000 visits and 23,000 page views. Most of these are via students Googling their course number or some other string and finding the appropriate page. These numbers indicate that the blog is widely used by students in their classes. In terms of ease and availability, the presence of the librarian's email address and the Meebo widget have lead to many messages and emails from students about their course work. As well, the demonstration of Meebo at the beginning of each classroom session has been an interesting and amusing way to start the class. It gets the students' attention right from the start by starting chat sessions with those that have their laptops with them. ${ }^{4}$

Overall, the blog has proven to be a useful part of the librarian's toolbox in educating and engaging students.

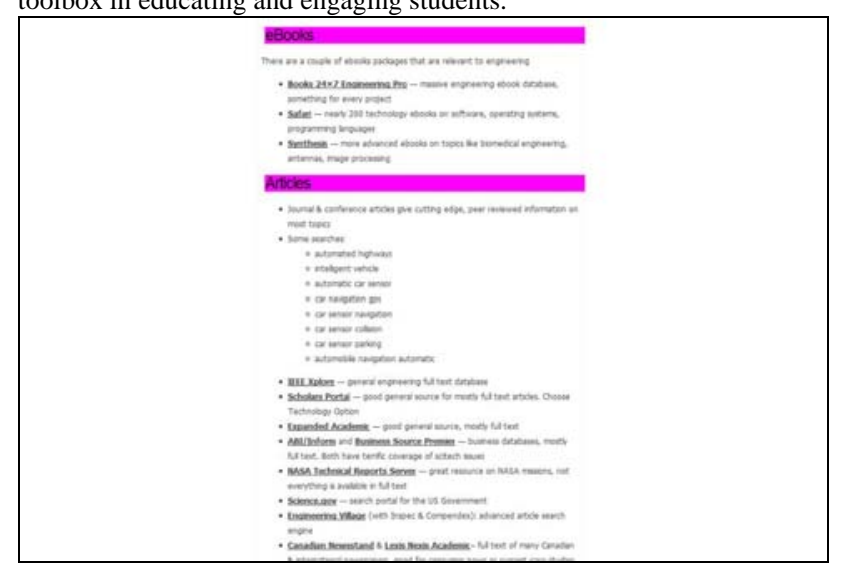

Figure 2: List of resources highlighted for Engineering 1000.

\section{REFERENCES}

1. Kolowich S. Professors and social media. InsideHigherEd. 2010. Available at:

http://www.insidehighered.com/news/2010/05/04/socialmedia. Accessed 16 May 2010.

2. Kirk DJ, Johnson TL. SWAM Meeting. 2010. Available at: http://delaney.typepad.com/files/kirk-johnson-swam-2010-proceedings1-1.pdf. Accessed 16 May 2010.

3. Eckford AW. Social media and the modern day classroom. Andrew Eckford: The Blog. 2010. Available at: http://andreweckford.blogspot.com/2010/02/social-media-and-modernday-classroom.html. Accessed 16 May 2010.

4. Dupuis J. Using a blog to engage students in the classroom and beyond! YULibrary News Spring 2010. 2010. Available at: http://www.library.yorku.ca/FacultyNews/Spring10/Teaching/SciBlog.ht m. Accessed 16 May 2010. 